Marta Ficoń

Uniwersytet Papieski Jana Pawła II w Krakowie

\title{
Antydemoniczny charakter sakramentu chrztu świętego i sakramentu bierzmowania
}

Kościół pielgrzymujący już od początku swego istnienia nieustannie dąży do wypełnienia misji, którą powierzył mu jego Założyciel Jezus Chrystus z woli Boga Ojca w Duchu Świętym. Trudzi się w każdej epoce historii, by doprowadzić do świętości wszystkich ludzi i oddać chwałę Bogu poprzez głoszenie Słowa Bożego, sprawowanie świętych obrzędów i uczynki miłosierdzia. Działając jednak na ziemi, Kościół zmuszony jest zmagać się ciągle z Szatanem i wszystkimi mocami zła, które przenikają świat i ludzkie serca, stawiając opór Zbawicielowi i Jego dziełu kontynuowanemu w Jego Mistycznym Ciele ${ }^{1}$.

Celem niniejszej refleksji jest ukazanie nieco zapomnianej współcześnie prawdy o sakramentach jako potężnych pomocach, które Chrystus pozostawił członkom Kościoła do dyspozycji w walce z rzeczywistością osobowego zła.

\section{Walka duchowa ${ }^{2}$}

Źródła Objawienia już od początku podkreślają, że poprzez odrzucenie Bożego daru za podszeptem diabła (por. $\mathrm{Rdz} 3,1-15$ ) ludzkość popadła w niewolę grzechu, a w takim zdegenerowanym i pożałowania godnym stanie nie mogła

\footnotetext{
1 Por. Jan Paweł II, Evangelium vitae [dalej: Ev] 103-104.

2 Jest to pierwszy z cyklu kilku artykułów poświęconych antydemonicznemu charakterowi wszystkich siedmiu sakramentów, stąd rozbudowane wprowadzenie do tematu.
} 
odeprzeć ataków kusiciela ani osiągnąć wiecznej szczęśliwości, wewnętrznej równowagi i pełni tożsamości istot stworzonych „na obraz i podobieństwo Boże” (Rdz 1, 26-27). Dlatego Bóg zesłał swego Syna, by dokonał Odkupienia poprzez złamanie potęgi Złego. Posłuszeństwo „księciu tego świata” (J 12, 31) zdegradowało człowieka, przysłoniło w nim obraz Boży i zaciemniło świadomość obdarowania przez Stwórcę. Poprzez Misterium Paschalne, czyli Krzyż i Zmartwychwstanie, Chrystus nie tylko pokonał moce ciemności, wyrwał człowieka $\mathrm{z}$ ich niewoli, ale przede wszystkim przywrócił utraconą przez człowieka godność i jedność: w sobie samym, z Bogiem, z drugim człowiekiem i ze światem przyrody. Odtąd odkupiony człowiek może dążyć do przemiany i pełni doskonałości, którą zdolny jest osiągnąć tylko dzięki zjednoczeniu ze swym Stwórcą i Zbawcą ${ }^{3}$. Wyzwolony, umocniony i wewnętrznie odnowiony przez dzieło Syna Bożego, którego miłość jest potężniejsza od wszelkiego zła, człowiek może wreszcie osiągnąć pełnię wolności (2 Kor 3, 17; Ga 2, 4; 5, 1. 13).

Pismo Święte akcentuje jednak również prawdę o tym, że jeśli człowiek odrzuci ten bezcenny dar, pozbawi się źródła wszelkiego życia i miłości, a w konsekwencji wpadnie w wewnętrzne rozdarcie i ciemności, kłamstwo o Bogu i o sobie samym, które było istotą grzechu początku (por. Rdz 3, 5). Zafałszowanie prawdy i zniszczenie życia łaski to cechy charakterystyczne diabła, „zabójcy od początku” i „ojca kłamstwa” (J 8, 44), który został definitywnie osądzony (por. $\mathrm{J} 16,11$ ), potępiony i pokonany (por. Łk 10, 18), a koniec jego panowania został wyznaczony przez Boga (por. Mt 25, 41). Jednak duch ciemności (por. Łk 22, 53; Kol 1, 13), „świadom, że mało ma czasu” (Ap 12, 12), pała gniewem ku ludziom wiernym Chrystusowi, próbuje wciągnąć ich w swój bunt przeciw Bogu i coraz gwałtowniej atakuje Jego Kościół (por. Mt 16, 18; Ap 12, 13-19).

Dlatego Magisterium Ecclesiae nieustannie przypomina, że niezbywalnym elementem życia chrześcijańskiego jest walka duchowa $\mathrm{z}$ „księciem tego świata” (J 12, 31), która trwa od początku stworzenia (por. Rdz 3, 1-15), a wplątany w nią człowiek musi nieustannie ciężko pracować, by wytrwać w dobru, i koniecznie potrzebuje pomocy Bożej łaski, by osiągnąć jedność w samym sobie ${ }^{4}$. Papieże wielokrotnie podkreślali jej kluczowe znaczenie w obronie przeciwko zasadzkom kusiciela. Ponadto, opierając się na przekazie Pisma Świętego, zaznaczali, iż chrześcijanin musi być wojownikiem, powinien czuwać, być mężnym (por.

3 Por. Jan Paweł II, Mulieris dignitatem [dalej: MD] 9, 11; tenże, Tertio millennio adveniente 7; Sobór Watykański II, Konstytucja Gaudium et spes [dalej: KDK] 2.

Por. KDK 37. 
$1 \mathrm{P} 5,8$; Jk 4, 7) oraz oprzeć swe życie duchowe na sakramentach i ascezie, a przede wszystkim na polecanych przez Zbawiciela modlitwie i poście (por.

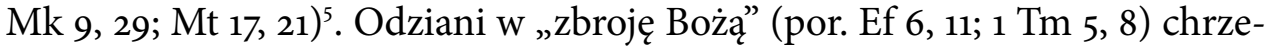
ścijanie nie powinni obawiać się Szatana, ale grzechu, który zawsze ma rys „diaboliczny”, czyli sieje zniszczenie w duszy człowieka, powoduje wewnętrzny rozkład i oddziela od innych ludzi, a szczególnie odciąga go od Stwórcy i Zbawcy. Wobec tego największą siłą chrześcijanina jest przylgnięcie do Boga, który „pragnie, by wszyscy ludzie zostali zbawieni i doszli do poznania prawdy” (1 Tm 2, 4). Z kolei „Zabójca od początku” i „ojciec kłamstwa” (J 8, 44) niestrudzenie sprzeciwia się prawdzie i zbawieniu, czyli obdarowaniu pełnią życia. Uzbrojony w moc Bożą chrześcijanin może mu się skutecznie opierać (por. Rz 8,31), a napełniony światłem Chrystusowej łaski i Jego obecnością, nie musi obawiać się, że zły duch powróci i wprowadzi w czyn swe niszczycielskie zamysły (por. Mt 12, 43-45; Łk 11, 24-26).

\section{Moc sakramentów}

Modlitwa i działanie chrześcijanina powinny być oparte i ciągle wzmacniane przez źródła łaski, jakimi są sakramenty święte. One pomagają mu „być w Chrystusie” (Rz 6, 5-14; 16, 20; Ef 6, 16), oddać Mu całe swe życie, wypełnić Nim myśli i działania czy wysławiać Jego potęgę, dobroć i miłosierdzie. Na sakramenty można patrzeć dwutorowo: w aspekcie pozytywnym, jako jednoczące z Chrystusem źródło zbawienia i szczęścia oraz obfite wylanie łaski, a także w aspekcie negatywnym, jako niszczące moc Szatana i jego władzę nad człowiekiem, który poddał się mocy ciemności poprzez swe zaangażowanie w grzech. Obie te perspektywy zazębiają się w jedną całość. Jako znaki i „nośniki” Bożej łaski stanowią źródło nieocenionej pomocy w życiu duchowym człowieka oraz umocnienie w walce duchowej z siłami zła; przede wszystkim jednak mają charakter interpersonalny, czyli są spotkaniem i komunią miłości z samym Bogiem. Każdy z sakramentów jest darem miłości Ojca przez Syna

\footnotetext{
5 Por. R. Laurentin, Szatan. Mit czy rzeczywistość?, przeł. T. Szafrański, Warszawa 1998, s. 226; EV 100; Jan Paweł II, Walka z szatanem, „L'Osservatore Romano” (wyd. pol.) 4 (242) (2002), s. 15; Franciszek, Przepiękna walka, http://www.osservatoreromano.va/pl/news/przepiekna-walka (7.11.2015).

6 Por. MD 9, przyp. 29; Jan Paweł II, Wierzę w Boga Ojca Stworzyciela, Città del Vaticano 1987, s. 361: diaballein to grecki czasownik oznaczający „powodować zniszczenie”, „dzielić”, „rzucać oszczerstwo”, „oszukiwać”.
} 
w Duchu Świętym. Ta miłość Trójcy Świętej uzdalnia wiernego do kroczenia drogą wiary, pokładania nadziei w Bożych obietnicach i odwzajemnienia miłości otrzymanej od Stwórcy jeszcze „przed założeniem świata” (J 17, 24).

Wszystkie te aspekty sakramentów mają ewidentnie wymiar antydemonicz$n y^{7}$, ponieważ są one przestrzenią spotkania ze Zbawicielem - Źródłem życia, świętości i światła (por. J 1, 4-5; 8, 12; 12, 46), który w człowieku zjednoczonym z Nim odnosi wielkie zwycięstwo nad istotą zanurzoną w śmierci, grzechu i ciemnościach (por. Mdr 2, 24; J 8, 44; Kol 1, 13). Warto pochylić się zatem nad prawdą o tym, jak wielkie znaczenie ma łaska sakramentalna, uzdalniająca chrześcijanina do życia zgodnego z Bożym zamysłem i do wyrażenia zdecydowanego sprzeciwu wobec podstępów złego ducha.

\section{Chrzest jako przejście z ciemności Szatana do światłości Chrystusa}

Pierwszym sakramentem, który może przyjąć człowiek, jest chrzest święty brama do pozostałych sakramentów i do innych bogactw Kościoła. Ma fundamentalne znaczenie dla życia duchowego, a konsekwencje jego udzielenia są znamienne i przełomowe dla całego człowieka. Jako „obmycie odradzające” powoduje przemianę ontologiczną w ten sposób, że człowiek staje się „nowym stworzeniem” przez Chrystusa w Duchu Świętym (por. 2 Kor 5, 17; Ga 6, 15). Ze starego człowieka, podległego Szatanowi i grzechowi, staje się nowym, który swą godność i wolność znajduje w Jezusie, dzięki Jego Męce, Śmierci i Zmartwychwstaniu'. Jego Pascha staje się naszą paschą, czyli przejściem ze śmierci do Życia, z ciemności do Światła (por. Ps 27, 1; 1 P 2, 9; J 8, 12; 12, 46; Ef $5,8.14 ; 1 \mathrm{~J} 1,7)$.

Przyjęcie sakramentu odrodzenia sprawia, iż człowiek wyrwany przez Chrystusa spod panowania diabła (por. $\mathrm{Dz} 10,38$ ) nie jest już obciążony żadnym grzechem, na czele z grzechem pierworodnym, który zakorzeniał go w egzystencjalnym „nie” wobec Boga. Wyzwolony spod panowania księcia ciemności stary człowiek umiera dla grzechu i rodzi się w nowej rzeczywistości Zbawiciela. Jako adoptowane dziecko Boże jest włączony w wewnętrzne życie Trójcy Świętej, a zatem żyje Bożym życiem, a tego Szatan nie potrafi znieść,

7 Skuteczność sakramentów w walce ze złym duchem jest w zewnętrznym aspekcie potwierdzona na przykład przez obserwację zachowań demonów obecnych w ludziach opętanych. Odnotowuje się ich gwałtowną nienawiść do obrzędów Kościoła, zwłaszcza sakramentalnych. Zob. Rytuał Rzymski. Egzorcyzmy i inne modlitwy błagalne, Katowice 2002, nr 16.

8 Por. M. Pyc, Teologalny wymiar chrztu świętego, [w:] Sentire cum Ecclesia, red. P. Podeszwa, Gniezno 2004, s. 334. 
dlatego nieustannie walczy, by człowiek swe szczęście i tę łaskę utracił. W tym celu kusiciel przeciwstawia się cnotom teologalnym ${ }^{9}$ zaszczepionym przez chrzest oraz przeciw cnotom moralnym, które na ich bazie powinny wzrastać. Tymczasem w tym sakramencie człowiek otrzymuje łaskę uświęcającą, łaskę usprawiedliwienia, która uzdalnia go do wiary w Boga, do pokładania w Nim nadziei, do miłowania Go ponad wszystko, do działania pod natchnieniem Ducha Świętego oraz do wzrastania w dobru i miłości ${ }^{10}$.

Obmycie wodami chrztu owocuje także włączeniem w Mistyczne Ciało Chrystusa i wspólnotę zbawienia, czyli Kościół, który jest szafarzem łaski Bożej, zwłaszcza obecnej w sakramentach. Sam jest „w Chrystusie niejako sakramentem, czyli znakiem i narzędziem wewnętrznego zjednoczenia z Bogiem i jedności całego rodzaju ludzkiego"'11. Duch ciemności jest przeciwnikiem zarówno zbawienia, jak i wszelkiej communio, dlatego, obserwując zbawienne działanie Kościoła w świecie, stara się rozbić go od środka wedle zasady „dziel i rządź”. Jednakże Kościół jest święty i mocny świętością i potęgą Trójcy Świętej, dlatego zgodnie z obietnicą Zbawiciela „bramy piekielne go nie przemogą" (Mt 16, 18).

\section{Elementy antydemoniczne $w$ starożytnej liturgii chrzcielnej}

Nie tylko teologia chrztu, ale również sam rytuał jego udzielania jest bardzo sugestywny i znaczący, jeśli chodzi o odrzucenie demona i jego wszelkiej aktywności. Już w starożytności chrześcijańskiej istniało kilka etapów tego obrzędu, wśród których dominowały akty egzorcystyczne, czyli odrzucające Szatana.

Podczas katechumenatu przeprowadzano egzorcyzmy przedchrzcielne, na które składały się modlitwy wzywające imienia Bożego i błagające o szybkie uwolnienie od diabła, a także obrzędy liturgiczne, polegające na tchnieniu w twarz katechumena oraz wyciśnięciu na jego czole znaku krzyża. Ta pierwsza czynność stanowiła symbol działania Ducha Świętego, który wypędzał demona, wyrażenie lekceważenia i wyrzeczenia się ducha ciemności oraz znak zniszczenia i usunięcia grzechu. Natomiast znak krzyża oznaczał przynależność do Chrystusa i był tarczą przeciw złemu duchowi ${ }^{12}$.

9 Zob. R. Laurentin, Szatan..., dz. cyt., s. 174-175.

10 Por. Katechizm Kościoła katolickiego [dalej: ккк] 1266.

11 Sobór Watykański II, Konstytucja Lumen gentium [dalej: KK] 1.

12 Por. B. Czyżewski, Teologiczne znaczenie egzorcyzmów chrzcielnych $w$ świetle katechez mistagogicznych IV i v wieku, [w:] Sentire cum Ecclesia, dz. cyt., s. 68-69, 72-73. O egzorcyzmach 
Szczytem walki katechumena $\mathrm{z}$ demonem były egzorcyzmy chrzcielne wyrażone $\mathrm{w}$ trzech etapach: egzorcyzmowanie wody chrzcielnej, obrzędy związane z wyrzeczeniem się Szatana oraz namaszczenie egzorcyzmowanym olejem $^{13}$.

Pierwszy z tych rytów był modlitwą epikletyczną i miał na celu nadanie wodzie przez Ducha Świętego mocy oczyszczenia i uświęcenia. Celebrans modlił się nad wodą, by zstąpiła nań Trójca Święta, a Duch Światłości usunął z niej wszelki ślad złego ducha ${ }^{14}$.

$\mathrm{Na}$ drugi obrzęd składały się cztery elementy. Pierwszy to ryt dotknięcia przez celebransa oczu i nozdrzy katechumena, zwany effatha, czyli „misterium otwarcia" i uzdrowienia zmysłów, by katechumen dostrzegł swą niedolę i zdołał wezwać pomocy Zbawiciela ${ }^{15}$.

Drugi element polegał najpierw na publicznym wyrzeczeniu się Szatana i jego zakus (apotaxis), a następnie na publicznym wyznaniu wiary w Chrystusa (syntaxis) jako wyrazie przejścia z niewoli demona do wolności. Początkowa część formuły zawierała wyrzeczenie się samej osoby diabła, a kolejna wszelkich przymiotów, spraw i działań Szatana (pompa diaboli) ${ }^{16}$, czyli przede wszystkim grzechu oraz wszystkich przeciwnych rozsądkowi czynów i myśli. Dopiero po tym akcie kandydat do chrztu mógł wyznać wiarę w Boga. Poprzez to zrywał wszelkie więzy łączące go $\mathrm{z}$ diabłem i przechodził na stronę Zbawiciela, który pokonał grzech, śmierć oraz złego ducha, czyniąc człowieka wolnym

przedchrzcielnych piszą już najstarsze źródła chrześcijańskie: „Kiedy przybliży się dzień, w którym [katechumeni] będą ochrzczeni, biskup egzorcyzmuje każdego z nich, żeby uznać, czy jest czysty", Hipolit Rzymski, Tradycja Apostolska 19, [w:] Chrzest i pokuta w Kościele starożytnym, oprac. J. Słomka, Kraków 2004, s. 42-43. „Kiedy małe dzieci lub dorastający przychodzą do sakramentu odrodzenia, nie wcześniej przystępują do źródła życia, zanim przez egzorcyzmy i tchnienia duchownych nie zostanie z nich wypędzony duch nieczysty", Indiculus, rozdz. 9.

${ }_{13}$ Por. B. Czyżewski, Teologiczne znaczenie..., dz. cyt., s. 74-79, 82-85, 89-92.

${ }_{14}$ Por. tamże, s. 74.

15 Por. tamże, s. $75-76$.

${ }_{16}$ Tertulian pisał w traktacie $O$ widowiskach, że w rycie chrzcielnym wyrzekamy się „diabła, jego przepychu i aniołów”, [w:] Chrzest i pokuta w Kościele starożytnym, dz. cyt., s. 154. Jan Chryzostom pytał: „Wyrzekam ci się, szatanie. Cóż się to stało? Co za dziwna i niespodziewana formuła? Ty, co się bałeś, co drżałeś, występujesz przeciw tyranowi? [...] Mam mocną broń odpowiadasz. Jaką broń, jaki sojusz? - powiedz mi. Łączę się z Tobą, Chryste! Oto dlaczego ufam i stawiam czoło. Mam mocną ucieczkę. Oto środek, który mnie uczynił mocniejszym niż ten, którego się bałem i przed którym drżałem; stąd nie tylko jego się wyrzekam, lecz i wszelkiej jego pychy", Jan Chryzostom, Katecheza 11, 6, [w:] tenże, Katechezy chrzcielne, przeł. W. Kania, Lublin 1993. 
i szczęśliwym. W celu przypieczętowania tego aktu namaszczano czoło znakiem krzyża $^{17}$. Formuła wyrzeczenia się Szatana była obowiązkiem katechumena i warunkowała otrzymanie chrztu świętego ${ }^{18}$.

Trzeci element to obrzęd cilicium, polegający na staniu, klęczeniu lub leżeniu na worze $\mathrm{z}$ włosia, który miał charakter pokuty za grzechy - owocu uległości wobec diabła. Ostatnim elementem tego obrzędu były gesty dramatyzujące, zwłaszcza w Kościele wschodnim, takie jak: odwracanie się z zachodu na wschód (por. Mt 24, 27), wyciąganie rąk, klękanie, wstawanie, plucie w stronę diabła. Wspomniane ryty miały na celu uwolnienie spod tyranii demona, były wyrazem pogardy dla niego, świadectwem wyparcia się go, ale równocześnie błaganiem o miłosierdzie Zbawiciela, by wejrzał na udręczonego przez złego ducha człowieka i uwolnił go mocą swej Męki, Śmierci i Zmartwychwstania. Po obmyciu chrzcielnym zewnętrznym wyrazem wyzwolenia z niewoli Szatana i odrodzenia było ubranie białej szaty ${ }^{19}$.

Trzeci obrzęd również wyrażał odrzucenie złego ducha poprzez namaszczenie egzorcyzmowanym olejem. Olej miał uzdrowić duszę, by człowiek mógł przeciwstawić się Szatanowi i usunąć z życia jego wszelkie przejawy. To także znak, że sam Chrystus walczy z duchem ciemności, a człowiek jest Jego żołnierzem, przynależy tylko do Niego ${ }^{20}$.

\section{Nowożytna liturgia chrzcielna}

Z biegiem wieków ryty egzorcystyczne ulegały redukcji, a formuły i gesty odnoszące się do Szatana przestały odgrywać tak znaczącą rolę w obrzędzie chrztu. Usunięto z niego trzy imperatywne egzorcyzmy chrzcielne, zastępując

${ }_{17}$ Zanim doszło do celebracji chrztu, katechumeni przygotowywali się do niego poprzez modlitwę i post, które pomagały pozbyć się wpływu złego ducha (por. Mk 9, 29; Mt 17, 21): „Gotujący się do chrztu niech poszczą w wigilię soboty [...]. Nakazuje się wszystkim im, aby modlili się i klęczeli. Kładąc na nich rękę swoją, nich on [biskup] zaklina wszelkie obce duchy, żeby się od nich oddaliły i więcej już do nich nie wracały. Po skończonych egzorcyzmach niech on tchnie na ich twarze i pobłogosławi im czoła, uszy i nozdrza oraz podniesie ich. [...] Kiedy prezbiter przyjmuje każdego z przystępujących do chrztu, niech nakaże mu się wyrzec, mówiąc: «Czy wyrzekasz się szatana i wszelkiej służby jemu i wszystkich jego spraw?». Po tym zaś, jak każdy się wyrzeknie, niech prezbiter pomaże go olejem egzorcyzmów, mówiąc: «Niech wszelki duch oddali się od ciebie». Przedstawia go następnie obnażonego biskupowi lub prezbiterowi, który stoi przy wodzie i chrzci”, Hipolit Rzymski, Tradycja Apostolska 19-20, [w:] Chrzest i pokuta w Kościele starożytnym, dz. cyt., s. $43-44$.

\footnotetext{
18 Por. B. Czyżewski, Teologiczne znaczenie..., dz. cyt., s. 76-79.

19 Por. tamże, s. 82-85, 88-89.

20 Por. tamże, s. 89-92.
} 
je dwiema formułami błagalnymi. Zachowany został starożytny i uroczysty rytuał wyrzeczenia się diabła stosowany przy chrzcie katechumenów w liturgii wielkanocnej ${ }^{21}$, natomiast podczas obrzędu chrztu dzieci jego brak dopuszczalny jest tylko w przypadku skróconego obrzędu do użytku katechetów oraz w wypadku niebezpieczeństwa śmierci dziecka, ale potem i tak odmawia się Modlitwę Pańską, która kończy się błaganiem: „I zbaw nas ode Złego”.

Wśród współczesnych rytów obecnych podczas chrztu dzieci znajduje się między innymi poprzedzające liturgię sakramentu naznaczenie znakiem krzyża jako symbol przynależności do Trójcy Świętej i Jej opieki oraz modlitwa powszechna zakończona modlitwą z egzorcyzmem, w której celebrans modli się, aby dziecko zostało przez Zbawiciela uwolnione od grzechu pierworodnego. W jednej z formuł prosi on Boga, który posłał swego Syna, „aby oddalił od nas moc szatana, ducha nieprawości, a człowieka wyrwanego z ciemności przeniósł do przedziwnego królestwa Twojej światłości”22 ${ }^{2}$ W innej formule błaga o umocnienie i opiekę Bożą nad dziećmi, które „będą narażone na pokusy tego świata i będą musiały walczyć przeciw zasadzkom szatana”23. Podczas obrzędu, tuż po poświęceniu wody, a przed wyznaniem wiary, rodzice i chrzestni wyrzekają się grzechu, wszystkiego, co prowadzi do zła, oraz „szatana, który jest głównym sprawcą grzechu" ${ }^{24}$.

Wśród rytów wyjaśniających, obecnych w Rytuale, znajduje się namaszczenie krzyżmem świętym, włożenie białej szaty i wręczenie zapalonej świecy, które są znakami Bożego umocnienia, czystości i przynależności do Chrystusa. Jest to także manifestacja umocnienia w przyszłej duchowej walce, bycia dziećmi światłości oraz odrzucenia wszelkich powiązań z Szatanem i z jego światem ciemności ${ }^{25}$.

Obrzędy chrztu dorosłych są bogatsze w symbolikę antydemoniczną i częściej podkreślają zwycięstwo Zmartwychwstałego nad grzechem, śmiercią i Szatanem ${ }^{26}$. Katechumenat składa się z trzech stopni, których elementy są bardzo podobne do rytów wczesnochrześcijańskich, $\mathrm{z}$ wyjątkiem treści dramatyzujących, nieprzystających już do nowożytnej liturgii.

${ }^{21}$ Por. R. Laurentin, Szatan..., dz. cyt., s. 100.

${ }_{22}$ Obrzędy chrztu dzieci dostosowane do zwyczajów diecezji polskich 49A, Katowice 2005.

${ }_{23}$ Tamże, 49B.

24 Tamże, 57.

25 Por. tamże, 62-65.

${ }^{26}$ Por. Obrzędy chrześcijańskiego wtajemniczenia dorosłych dostosowane do zwyczajów diecezji polskich 86, Katowice 1988. 
Pierwszy etap zawiera obrzędy przyjęcia do katechumenatu, podczas których celebrans mówi do kandydatów do chrztu o świetle Zbawiciela i postępowaniu w światłości ${ }^{27}$, a następnie tam, gdzie żywe są jeszcze kulty pogańskie, Rytuał przewiduje wyrzeczenie się wierzeń nieprowadzących do kultu jedynego Boga oraz egzorcyzm fakultatywny, kiedy celebrans tchnie w twarz kandydata i mówi: „Panie, odpędź złe duchy tchnieniem ust swoich, nakaż im odejść, bo przybliżyło się Twoje królestwo"28. Przy końcu obrzędu naznacza jego czoło i narządy zmysłów znakiem krzyża jako dowód miłości Chrystusa - Drogi, Prawdy i Życia, oraz Jego zwycięstwa nad niewolą grzechu, śmierci i ducha ciemności ${ }^{29}$.

Uczęszczając na liturgię słowa, katechumeni mogą uczestniczyć w egzorcyzmach mniejszych, które można stosować w różnych okolicznościach, a nawet jeszcze przed rozpoczęciem katechumenatu ${ }^{30}$. Składają się nań modlitwy błagalne, w których celebrans poleca katechumenów Trójjedynemu Bogu, by raczył ich uwolnić od wszelkich wpływów złego ducha oraz oddalił wszelki błąd i grzech ${ }^{31}$; by odsunął od nich „ducha kłamstwa, żądzy i nieprawości”" ${ }^{2}$ oraz ducha "chciwości, zmysłowości i pychy”" Modlitwy te skupiają się na ukazaniu kandydatom do chrztu konieczności zwrócenia się o pomoc do Boga w codziennej walce z siłami ciemności i zła, które próbują wykorzystać doznania zmysłowe przeciwko prymatowi życia duchowego w osiągnięciu życia wiecznego.

Drugi etap, zwany „obrzędem wybrania” bądź „okresem oczyszczenia i oświecenia”, odbywa się w Wielkim Poście. Jego cechę charakterystyczną stanowią trzy zakończone egzorcyzmami skrutynia, czyli modlitwy Kościoła nad wybranymi, by Bóg oczyścił ich umysły i serca, umocnił przeciw pokusom, pobudził wolę, by bardziej przylgnęli do Zbawiciela i uczynili postępy w miłości ku Bogu ${ }^{34}$. Obrzędy egzorcyzmów po każdym skrutynium uwalniają ich od skutków grzechu i władzy złego ducha, umacniają w życiu duchowym i otwierają na przyjęcie darów Chrystusa Zbawcy ${ }^{35}$.

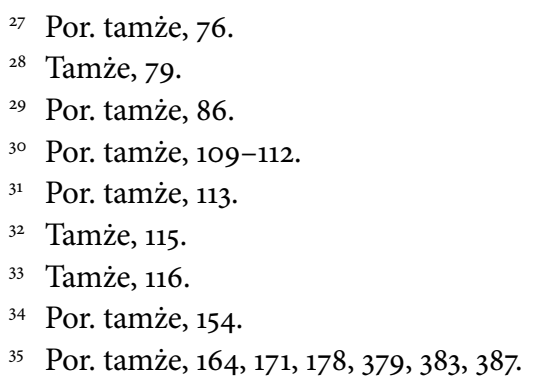


Trzeci etap to liturgia chrztu świętego, którego jednym z głównych punktów jest wyrzeczenie się Szatana, jego spraw i pychy ${ }^{36}$ oraz wyznanie wiary. To jeden obrzęd, który pomaga wejść w przestrzeń miłości Trójcy Świętej i pokładać nadzieje jedynie w Zbawcy rodzaju ludzkiego. Dalsze obrzędy, na czele $z$ obmyciem chrzcielnym, a potem założeniem białej szaty i przekazaniem światła, skutkują nowym stworzeniem, które zanurza się w Bożym miłosierdziu i światłości, staje się częścią duchowej budowli Mistycznego Ciała Chrystusa i zyskuje przemożną broń do walki z największym nieprzyjacielem człowieka.

Jako brama do innych sakramentów i życia chrześcijańskiego, chrzest jest poważnym ciosem dla „węża starodawnego” (Ap 12, 9), który opiera swe panowanie nad człowiekiem na grzechu. Łaska chrztu odpuszcza wszystkie grzechy, oczyszcza człowieka ze zła, a w konsekwencji od wszelkiej styczności z diabelską niegodziwością. Daje również umocnienie w późniejszym odważnym kroczeniu drogą życia chrześcijańskiego, które narażone jest nieustannie na ataki sił zła. Do odparcia tych ataków służą też inne sakramenty, które Syn Boży ustanowił z miłości do człowieka.

Bierzmowanie jako umocnienie w walce z siłami ciemności

Kolejny sakrament wtajemniczenia chrześcijańskiego, bierzmowanie, stanowi umocnienie łaski otrzymanej w chrzcie świętym. Sprawia ono, że chrześcijanie, czyli ci, którzy zostali namaszczeni, mogą głębiej uczestniczyć w misji Zbawiciela i w pełni Ducha Świętego, którą On posiada, aby całe ich życie było Nim przeniknięte ${ }^{37}$. Otrzymują oni Dar szczególny - samego Ducha Świętego, będącego Duchem Prawdy, obiecanym przez Jezusa Chrystusa Parakletem, który staje w obronie człowieka jako Pocieszyciel i Orędownik, zwłaszcza wtedy, gdy swymi potępiającymi sądami atakuje go Szatan ${ }^{38}$. Otrzymawszy pierwsze dary Ducha w chrzcie, a potem kolejne w bierzmowaniu, chrześcijanie mogą liczyć, że będzie On Stróżem ich nadziei, a jako Źródło Prawdy i Miłości pomoże im czynić dobro, ześle radość i pociechę w chwilach cierpienia, uzdolni do rozwinięcia łask i cnót, by prowadziły do zbawienia, czyli uczestnictwa w życiu Boga-Miłości. W Duchu Świętym człowiek znajduje

${ }_{36}$ Por. tamże, 217.

37 Por. KKK 1294.

${ }^{38}$ Hebr. słowo śātān oznacza „przeciwnik”, „oponent”, „oskarżyciel”, zob. R. Zając, Szatan w Starym Testamencie, Lublin 1998, s. 15. 
również sprawiedliwość, pokój i radość - cechy charakterystyczne królestwa Bożego (por. Rz 14, 17; Ga 5, 22) ${ }^{39}$.

Największy wróg ludzkości, diabeł, stara się nieustannie siać nieporozumienia i konflikty, wzmagać bezbożność i pychę, wewnętrzną pustkę i niepokój, a wiarę zniweczyć bądź namówić człowieka, by zachował ją tylko i wyłącznie dla siebie. Tymczasem sakrament bierzmowania przeciwdziała tym przewrotnym i ukrytym działaniom w różnych wymiarach: eklezjalnym (udoskonala więź z Kościołem, pomaga budować go w wierze, nadziei i miłości), umacniającym (bierzmowani otrzymują dary i szczególną moc Ducha Świętego, która głębiej zakorzenia w Bożym synostwie, upodabnia do Zbawiciela i ściślej z Nim jednoczy) oraz profetycznym (umacnia do mężnego dawania świadectwa Chrystusowi oraz do szerzenia i do obrony wiary $)^{40}$. Dlatego łaska sakramentalna stanowi moc w walce duchowej i jest niezbędna do obrony przed zakusami złego ducha oraz chroni przed załamaniem się w żarliwości chrześcijańskiej. Ponadto Duch Święty uwrażliwia bierzmowanych na obecność i działanie sił ciemności w świecie (por. J 16, 8-11), jednakże świadomości potęgi zła musi towarzyszyć przekonanie o sile Zbawiciela przezwyciężającej wszystko. Moc Ducha daje prawdziwą wolność (por. 2 Kor 3, 17), a Jego dary uzdalniają do walki z kusicielem.

\section{Dary Ducha Świętego wobec aktywności ducha kłamstwa}

Poprzez owe siedem darów otrzymanych w sakramencie bierzmowania zyskuje się umocnienie, dopełnienie i udoskonalenie cnót oraz pomoc $\mathrm{w}$ chętnym poddawaniu się Bożym natchnieniom. Szatan, nie mogąc bezpośrednio uderzyć w Boga, obiera sobie za cel Jego umiłowane stworzenie, w którym istnieje Jego obraz i podobieństwo. Pragnąc odciągnąć człowieka od Źródła życia, a potem zanurzyć go w ciemność i śmierć (por. Mdr 2, 24), sprzeciwia się aktywności Ducha Świętego i konsekwencjom Jego darów. Działając poprzez wyszukane i podstępne pokusy, nakłania człowieka do grzechu. Jeśli serce ludzkie ulegnie, wówczas jest najbardziej podatne na manipulację przez ducha kłamstwa.

Darowi mądrości, czyli rozeznaniu w sprawach Bożych, przeciwstawia głupotę polegającą na niezrozumieniu Bożego zbawczego planu miłości zawartego w źródłach Objawienia, na niedostrzeganiu sensu w stworzeniu i na zawężeniu życia do doczesności (por. Łk 12, 16-23).

39 Por. Jan Paweł II, Dominum et Vivificantem [dalej: Dv] 67.

40 Por. KK 11; KKк 1303; Sobór Watykański II, Dekret Ad gentes divinitus 11. 
Trafne rozumienie spraw Bożych i ich związków z człowiekiem, czyli dar rozumu, spotyka się ze strony „ojca kłamstwa” $(J$ 8, 44) z oporem w postaci duchowej bezmyślności, nieznajomości podstawowych prawd wiary, a w konsekwencji wciągnięcia w kłamstwo o Bogu i człowieku, czyli ateistyczne i wszeteczne prądy myślowe (por. 2 P 2, 1-2).

Błędne ukierunkowanie swego życia na zachowania łatwe, lekkie i przyjemne, niezwiązane z wysiłkiem i cierpieniem, ale jednocześnie prowadzące do rozkładu moralnego, niepokoju i lęku (por. 2 P 2, 13-14. 18-19; Mt 19, 7-9), skonfrontowane jest $\mathrm{z}$ darem rady jako rozeznaniem $\mathrm{w}$ moralnych zawiłościach życia, umożliwiającym podjęcie właściwej decyzji pośród wątpliwości moralnych i wiodącym do pokoju ducha.

Dar męstwa, czyli uwolnienie od lęku przed śmiercią, chorobami, bólem i trudami dzięki czerpaniu mocy z samego Boga, odrzuca postawę wycofania się, tchórzostwa i chronicznego lęku oraz brak pokładania nadziei w Bogu (por. 1 P 5, 6-10).

Z kolei dobre rozeznanie wartości, budowanie wiedzy o sobie i o innych na prawdzie o Bogu, zwane darem umiejętności, pozwala uniknąć wynikającego z braku oparcia na autorytecie Bożego Objawienia błądzenia po omacku, jeśli chodzi o rozum i o ducha. W wyniku diabelskich intryg człowiek stwarza fałszywy obraz Stwórcy i samego siebie (por. Rdz 3, 1-15), a wskutek tego karmi się pustymi emocjami uznanymi za wartości.

Dziełem Szatana jest również bezbożność, pogarda względem Zbawcy, traktowanie Go jako wymysłu ludzkiego rozumu bądź ciemiężyciela, a Kościoła jako zbrodniczej organizacji chcącej zniewolić i wyzyskać swych wyznawców. Historia już wielokrotnie pokazała, że filozofia niewrażliwości na Boga i okazanie Mu wzgardy nie prowadzą do wyzwolenia, lecz do zagłady człowieka ${ }^{41}$. Lekiem na tę sytuację jest przyniesiony przez Ducha Świętego w sakramencie bierzmowania dar pobożności, uzdalniający do traktowania Boga jak Ojca, a bliźnich jak braci - z miłością, łagodnością i serdecznością.

Natomiast dar bojaźni Bożej chroni przed pychą i duchowym zarozumialstwem, uważaniem siebie samego za samowystarczalnego i stawianiem siebie na równi z Bogiem (por. $\mathrm{Rdz} 3,5$ ). Jako poczucie własnej słabości w miłowaniu Boga dar ów uzmysławia, iż człowiek ciągle musi się starać, by być takim, jakim go Bóg chce mieć. Kiedy osiągnie ten cel, wtedy dopiero uzyska pełnię szczęścia.

${ }^{41}$ Por. DV 38. 


\section{Liturgia sakramentu bierzmowania jako triumf Ducha Ożywiciela}

Do odrzucenia wszystkiego, co pochodzi od Złego, nawiązuje także sama liturgia sakramentu bierzmowania. Jeśli nie odbywa się ono w ramach jednej akcji liturgicznej wraz z chrztem i Eucharystią, wtedy kandydaci odnawiają przyrzeczenia chrzcielne. Najpierw biskup pyta każdego z nich, czy wyrzeka się „szatana, wszystkich jego spraw i pokus”, a po odpowiedzi: „Wyrzekam się”, następuje wyznanie wiary ${ }^{42}$.

Znaczący jest również ryt błogosławienia krzyżma świętego, a w Kościołach wschodnich - myronu. W liturgii syryjskiej w Antiochii epikleza jego poświęcenia unaocznia, że stanie się on dla wszystkich namaszczonych „szatą światła, płaszczem zbawienia, darem duchowym, uświęceniem duszy i ciała, szczęściem nieprzemijającym, niezatartą pieczęcią, puklerzem wiary i tarczą ochronną przeciwko wszystkim zakusom Nieprzyjaciela"43. Podczas namaszczenia zebrani śpiewają epikletyczny hymn do Ducha Stworzyciela i Pocieszyciela, który jako „zdrój żywy, miłość, ognia żar” stanowi „namaszczenie dusz”. Duch Święty jawi się w nim jako Miłość Najwyższego Boga obdarzająca siedmiorakimi darami, wymownym językiem, światłą myślą, miłością i mocą, by bierzmowani mogli stać się doskonalszymi chrześcijanami mocno ugruntowanymi w wierze i by potrafili nieść Chrystusa wszystkim ludziom. W tym celu autor hymnu prosi, by Duch Światłości odpędził w dal „nieprzyjaciela” i obdarzył swym pokojem. Wówczas kierowani Jego natchnieniami bierzmowani, krocząc przez życie, są zdolni omijać kuszące ich zło. Hymn zakończony jest wyrażeniem pragnienia poznania i oddania chwały Trójcy Świętej ${ }^{44}$.

Jeszcze bardziej wymownym świadectwem przedziwnego i potężnego działania Ducha jest sekwencja liturgiczna, w której jawi się jako „Ojciec ubogich”, Dawca łask i Światłość sumień, wlewając w serca niezwykłą radość, spełnienie i pocieszenie. Stworzenie bez Jego ożywczego tchnienia usycha w marności i cierpieniu, tkwiąc w beznadziei i inercji. Dlatego bierzmowani błagają Go o całościowe uzdrowienie - ciała, woli i serca, aby nie były podatne na pokusy doczesności, na zamknięcie się w sobie i obranie błędnej ścieżki życia ${ }^{45}$. Stąd konieczność obecności Ducha i Jego siedmiorakich darów, by mogli osiągnąć wieczne szczęście, odważnie głosząc miłość Boga w świecie.

${ }_{42}$ Por. Obrzędy bierzmowania dostosowane do zwyczajów polskich 23, Katowice 1995; Sobór Watykański II, Konstytucja Sacrosanctum Concilium 71.

43 KKK 1297.

44 Por. Obrzędy bierzmowania..., dz. cyt., s. 106-107.

45 Tamże, s. 107-108. 
Doniosłe jest również odmówienie Modlitwy Pańskiej, ponieważ Duch modli się w wiernych, którzy w Nim mogą powiedzieć „Abba, Ojcze” oraz błagać o wybawienie od Złego ${ }^{46}$.

Bez pomocy łaski Bożej chrześcijanin nie może doskonalić się w wierze i ciągle wpada w pułapki złego ducha, dlatego bierzmowani, umocnieni Duchem Świętym, jeśli tylko zechcą, będą potrafili skutecznie z nim walczyć, ponieważ tam, gdzie „ojciec kłamstwa” (J 8, 44) stara się stłumić głos sumienia człowieka, Duch Prawdy subtelnie pobudza je poprzez wyrzuty; tam, gdzie kusiciel i „przewrotny geniusz podejrzeñ" 47 prowadzi do konfliktów, tam Duch Jedności łączy ludzi na nowo (por. Dz 2, 4-11); tam, gdzie „oskarżyciel” (por. Za 3, 1; Ap 12,10 ) wydaje na człowieka wyroki potępienia, tam Duch Ożywiciel z mocą przychodzi mu na ratunek, obdarzając swymi darami i wyciskając niezatarte duchowe znamię jako znak całkowitej przynależności do Chrystusa, trwałego oddania się na Jego służbę oraz mocy wyznawania Go publicznie ${ }^{48}$.

Dlatego sakrament bierzmowania jest niezbędny w dążeniu do chrześcijańskiej doskonałości i nie tyle do odpierania szatańskich ataków, co do uświadomienia sobie przede wszystkim trwającej zawsze miłości Trójcy Świętej ku każdemu człowiekowi, w obliczu której nie ostoi się żadne zło.

\section{$* * *$}

Wspomniane powyżej aspekty rzeczywistości sakramentalnej chrztu i bierzmowania ukazują nadaną im przez Boga moc odrzucającą wszelkie misterium iniquitatis. Ta rzadko dostrzegana płaszczyzna ich rozumienia może i powinna stać się bodźcem do rozwoju sakramentologii nie tylko w kierunku teoretycznych rozważań, ale przede wszystkim dynamicznej praktyki wiary, zwłaszcza na początkowym etapie życia chrześcijańskiego.

\section{AbstrakT}

Antydemoniczny charakter sakramentu chrztu świętego i sakramentu bierzmowania

Szatan jako „ojciec kłamstwa” i „zabójca od początku” (J 8, 44) jest nieprzyjacielem człowieka i Kościoła, który nieustannie stara się zniszczyć. Jednak Chrystus wyposażył

\footnotetext{
46 Tamże, Wprowadzenie teologiczne i pastoralne 13.

47 DV 37.

${ }^{48}$ Por. KKK 1296, 1305.
} 
swój Kościół w sakramenty, które są źródłem Jego łaski i spotkaniem z Trójcą Świętą. Jako takie stanowią potężną broń przeciwko mocom ciemności. Chrzest przenosi ludzi spod władzy diabła, grzechu i śmierci do Królestwa Bożego, pełnego życia i światła. Bierzmowanie umacnia ochrzczonych w walce przeciwko pułapkom demona.

\section{SŁOWA KLUCzowe}

walka duchowa, sakramenty, chrzest, bierzmowanie, Zbawiciel, Duch Święty, Szatan

\section{Abstract}

\section{Antidemonic feature of sacraments. Baptism and Confirmation}

Satan as "the father of lies" and "murderer from the beginning" (Jn 8:44) is the enemy of man and of the Church that he continually intends to destroy. But Christ has endowed his Church with the sacraments which are sources of His grace and the encounter with the Holy Trinity. As such, they constitute a powerful weapon against the forces of darkness. Baptism transfers humans from the power of the devil, sin and death to Kingdom of God, full of life and light. Confirmation strengthens the baptized in the fight against traps of the demon.

\section{KEYWORDS}

spiritual combat, sacraments, Baptism, Confirmation, the Saviour, the Holy Spirit, Satan

\section{BIBLIOGRAFIA}

Chrzest i pokuta w Kościele starożytnym, oprac. J. Słomka, Kraków 2004.

Czyżewski B., Teologiczne znaczenie egzorcyzmów chrzcielnych $w$ świetle katechez mistagogicznych IV $i$ V wieku, [w:] Sentire cum Ecclesia, red. P. Podeszwa, Gniezno 2004, s. 67-92.

Franciszek, Przepiękna walka, http://www.osservatoreromano.va/pl/news/przepiekna-walka (7.11.2015).

Indiculus, [w:] Breviarium fidei, Poznań 2007, s. 53-58.

Jan Chryzostom, Katechezy chrzcielne, przeł. W. Kania, Lublin 1993.

Jan Paweł II, Encyklika Dominum et Vivificantem, Wrocław 1994.

Jan Paweł II, Encyklika Evangelium vitae, Wrocław 1995.

Jan Paweł II, List apostolski Mulieris dignitatem, Watykan 1988.

Jan Paweł II, List apostolski Tertio millennio adveniente, [w:] tenże, Wielki Jubileusz

Roku 200o, Città del Vaticano 2001, s. 7-52.

Jan Paweł II, Walka z szatanem, „L'Osservatore Romano” (wyd.pol.) 4 (242) (2002), s. 15. 
Jan Paweł II, Wierzę w Boga Ojca Stworzyciela, Città del Vaticano 1987.

Katechizm Kościoła katolickiego, Poznań 1994.

Laurentin R., Szatan. Mit czy rzeczywistość?, przeł. T. Szafrański, Warszawa 1998.

Obrzędy bierzmowania dostosowane do zwyczajów polskich, Katowice 1995.

Obrzędy chrześcijańskiego wtajemniczenia dorostych dostosowane do zwyczajów diecezji polskich, Katowice 1988.

Obrzędy chrztu dzieci dostosowane do zwyczajów diecezji polskich, Katowice 2005.

Pyc M., Teologalny wymiar chrztu świętego, [w:] Sentire cum Ecclesia, red. P. Podeszwa, Gniezno 2004, s. 327-346.

Rytuał Rzymski. Egzorcyzmy i inne modlitwy blagalne, Katowice 2002.

Sobór Watykański II, Dekret Ad gentes divinitus, [w:] tenże, Konstytucje, dekrety, deklaracje, red. M. Przybyl, Poznań 2002, s. 433-471.

Sobór Watykański II, Konstytucja Gaudium et spes, [w:] tenże, Konstytucje, dekrety, deklaracje, red. M. Przybył, Poznań 2002, s. 526-606.

Sobór Watykański II, Konstytucja Lumen gentium, [w:] tenże, Konstytucje, dekrety, deklaracje, red. M. Przybył, Poznań 2002, s. 104-163.

Sobór Watykański II, Konstytucja Sacrosanctum Concilium, [w:] tenże, Konstytucje, dekrety, deklaracje, red. M. Przybył, Poznań 2002, s. 48-78.

Zając R., Szatan w Starym Testamencie, Lublin 1998. 